\title{
PENGEMBANGAN KOSAMI (KOMIK SAKU MATEMATIKA) BAGI SISWA KELAS VII SMP NEGERI 7 TARAKAN
}

\author{
Syafitri Eva Susanti ${ }^{1}$, Hariaty Hamid ${ }^{2}$, Nurmala $\mathrm{R}^{3}$ \\ ${ }^{1}$ Mahasiswa Strata 1 Pendidikan Matematika, Universitas Borneo Tarakan \\ ${ }^{2,3}$ Jurusan Pendidikan Matematika, Universitas Borneo Tarakan \\ syafitri.eva.12@gmail.com \\ hariaty.pmat@gmail.com \\ nurmala.r17@gmail.com
}

\begin{abstract}
The development model used is the Borg and Gall model of Sugiyono modification. In the Borg and Gall model, the Sugiyono modification consists of 10 stages, namely Potential and Problems, Data Collection, Product Design, Design Validation, Design Revision, Product Testing, Product Revision, Usage Testing, Product Revision and Mass Production. The media testing phase is done through 2 stages, namely the assessment of experts and user response. In the assessment of experts validated by material experts, media experts and linguists. While the user response was tested by 30 students and 2 mathematics teachers. The results of analysis shows that the kosami product developed based on validation by material experts obtained a feasible category with a percentage of $79.68 \%$, media experts obtained the category of Very Eligible with a percentage of $92.72 \%$ and linguists obtained the Very Eligible category with a percentage of $83.33 \%$. While the result of research in the field by the response of teacher user obtained a percentage of $75 \%$ with a Very Practical category, responses of student users obtained by $87,33 \%$ with a Very Eligible category, and responses of student users obtained by $90,67 \%$ with a Very Practical category . Because it has fulfilled the feasible and practical requirements of a Kosami learning media consisting of aspects of material feasibility, media feasibility, feasibility of language use, and practicality of user response, the kosami can be used as a feasible and practical learning media for students of clas VII SMP Negeri 7 Tarakan on Number Material.
\end{abstract}

Keywords: Development, KOSAMI, Media for learning mathematics.

\begin{abstract}
Abstrak
Model pengembangan yang digunakan adalah model Borg and Gall modifikasi Sugiyono. Pada model model Borg and Gall modifikasi Sugiyono terdiri dari 10 tahapan yaitu Potensi dan Masalah, Pengumpulan Data, Desain Produk, Validasi Desain, Revisi Desain, Ujicoba Produk, Revisi Produk, Ujicoba Pemakaian, Revisi Produk dan Produksi Masal. Tahap pengujian media melalui 2 tahapan yaitu penilaian para ahli dan respon pengguna. Pada penilaian para ahli di validasi oleh ahli materi, ahli media dan ahli bahasa. Sedangkan respon pengguna dilakukan pengujian 30 siswa dan 2 guru matematika. Hasil analisis menunjukkan bahwa produk kosami yang dikembangkan berdasarkan validasi oleh ahli materi memperoleh kategori Layak dengan persentase 79,68\%, ahli media memperoleh kategori Sangat Layak dengan persentase 92,72\%, ahli bahasa memperoleh kategori Sangat Layak dengan persentase 83,33\%, respon guru memperoleh kategori Layak dengan persentase $75 \%$ dan respon siswa memperoleh kategori Sangat Layak dengan persentase sebesar 90,67\% . Sedangkan dari hasil penelitian di lapangan oleh respon pengguna guru diperoleh persentase $72,5 \%$ dengan kategori Praktis, respon pengguna siswa pada kelayakan diperoleh persentase 87,33\% dengan kategori Sangat Layak dan respon pengguna pada kepraktisan diperoleh persentase 90,67\% dengan kategori Sangat Praktis. Karena telah memenuhi syarat layak dan praktis suatu media pembelajaran kosami yang terdiri dari aspek kelayakan materi, kelayakan media, kelayakan penggunaan bahasa, dan kepraktisan respon pengguna, maka kosami dapat digunakan sebagai media belajar yang layak dan praktis untuk siswa kelas VII SMP Negeri 7 Tarakan pada Materi Bilangan.
\end{abstract}

Kata kunci: Pengembangan, KOSAMI, Media Pembelajaran Matematika.

Matematika adalah salah satu mata pelajaran yang sangat penting dalam dunia pendidikan khususnya di sekolah karena matematika merupakan ilmu yang dapat melatih untuk berpikir kritis, sistematis, logis, dan kreatif. Matematika juga merupakan salah satu mata pelajaran yang kurang 
disukai oleh para siswa. Hal ini dikarenakan proses pembelajaran yang kurang optimal baik dari segi guru, siswa, media, maupun metode pembelajarannya. Sering kali dengan banyaknya jam pelajaran matematika dan banyaknya materi yang ada membuat siswa merasa jenuh dan bosan dalam belajar matematika. Selain itu potensi dalam lingkungan siswa juga belum dimanfaatkan secara maksimal. Sehingga perlu inovasi pembelajaran dengan memanfaatkan media pembelajaran dalam lingkungan sekitar siswa yang dapat menunjang proses pembelajaran.

Berdasarkan hasil wawancara terhadap guru matematika dan siswa kelas VII SMPN 7 Tarakan diperoleh informasi bahwa dalam proses pembelajaran guru menggunakan buku teks, papan tulis dan LKS (Lembar Kegiata Siswa). Buku teks/ pegangan yang digunakan dirasa kurang menarik bagi siswa dikarenakan kalimat terlalu panjang dan ukuran buku teks yang kurang praktis untuk dibawa kemana saja, hal ini menjadikan siswa kurang tertarik dalam membaca maupun mempelajari buku teks. Siswa tidak memiliki referensi lain di luar buku teks dan LKS yang dapat membantu siswa untuk belajar secara mandiri.

Selain itu, pada saat peneliti melakukan observasi di SMP Negeri 7 Tarakan, pembelajaran yang digunakan oleh guru masih menggunakan pembelajaran konvesional yaitu dengan metode ceramah, sehingga siswa merasa bosan dan mengalihkan kebosanan dengan membuat gaduh, berdiskusi sendiri dengan temannya, dan tidak memperhatikan guru yang sedang mengajar. Siswa juga kurang tertarik ketika diarahkan untuk membaca buku mata pelajaran, siswa cenderung mencari gambar yang ada di dalam buku mata pelajaran tersebut.

Oleh karena itu, dengan adanya media pembelajaran yang menyenangkan dan mengesankan untuk siswa, siswa tidak lagi mengalihkan kebosanan dengan membuat gaduh atau berdikusi sendiri dengan teman. Media pembelajaran dapat digunakan sebagai alat bantu untuk mempermudah tugas guru dalam menyampaikan berbagai bahan dan materi pelejaran, serta mengefektifkan dan mengefisiensikan anak didik dalam memahami materi dan bahan pelajaran tersebut (Indriana, 2011 : 13). Saat ini dengan berkembangnya teknologi informasi banyak sekali yang dapat digunakan sebagai media pembelajaran, diantaranya yaitu media komik dan buku saku. Dimana media komik merupakan media dalam bentuk kartun yang mengungkapkan karakter dan memerankan suatu cerita yang rata dihubungkan dengan gambar dan dirancang untuk memberikan hiburan kepada pembaca. Sedangkan buku saku merupakan media dua dimensi non-proyeksi, buku saku merupakan media yang praktis pada penggunaanya yang tidak tergantung pada listrik saat digunakan, penyimpanan dan pemeliharaanya mudah, serta tahan digunakan berkali-kali. Buku saku (pocket book) adalah buku dengan ukuran kecil, ringan, bisa disimpan di saku dan praktis untuk dibawa serta dibaca (Hizair, $2013: 108)$.

Media komik saku diharapkan dapat mendukung proses pembelajaran menjadi lebih inspiratif, menyenangkan, dan mengesankan siswa untuk lebih aktif dalam proses pembelajaran. Oleh karena itu, peneliti mengajukan judul “ Pengembangan KOSAMI (Komik Saku Matematika) Untuk Siswa Kelas VII SMP Negeri 7 Tarakan. Tujuan penelitian pengembangan ini adalah untuk 
mengembangkan komik saku matematika untuk SMP kelas VII semester 1 yang layak dan praktis digunakan.

Menurut Arsyad (2014:10), media pembelajaran adalah segala sesuatu yang digunakan untuk menyampaikan pesan atau informasi dalam proses belajar mengajar sehingga dapat merangsang perhatian dan minat siswa dalam belajar. Rusman (2012: 162), media belajar adalah alat yang siswa gunakan untuk mengerti dan memahami sesuatu dengan mudah dan mengingatnya dalam waktu yang lama. Dengan kata lain, media dapat mendukung proses pembelajaran. Penyampaian materi dapat dilakukan secara efektif dan efisien.

Menurut Susilana (2007:186) komik didefinisikan sebagai bentuk kartun yang mengungkapkan karakter dan menerapkan suatu cerita yang erat hubungannya dengan gambar dan dirancang untuk memberikan hiburan kepada para pembaca. Buku komik menyediakan cerita yang sederhana, mudah ditangkap dan dipahami isinya, sehingga digemari baik oleh anak-anak maupun orang dewasa. Hal lain juga diungkapkan oleh McCloud (2008:6) yang menyebutkan bahwa komik adalah juxtaposed pictortial and other images in delibrate sequence, inteded convey information and/or produce an aeshetic response in the reader. Sedangkan, buku saku (pocket book) adalah buku dengan ukuran kecil, ringan, bisa disimpan di saku dan praktis untuk dibawa serta dibaca (Sulistyani, 2013). Jadi, menurut pendapat peneliti, Komik Saku Matematika adalah suatu media pembelajaran yang berisi gambar/tokoh dan tulisan yang menceritakan suatu alur cerita tentang mata pelajaran matematika dengan ukuran yang berukuran kecil sehingga bisa disimpan di saku dan dapat dibawa kemana saja dengan praktis dan dapat memudahkan dalam penyimpanannya.

\section{METODE}

Jenis penelitian yang digunakan dalam penelitian ini adalah jenis penelitian dan pengembangan( Research and Development). Model penelitian dan pengembangan yang digunakan ialah model pengembangan Borg and Gall yang dimodifikasi oleh Sugiyono, langkah-langkah penelitian dan pengembangan ditunjukkan pada diagram berikut :

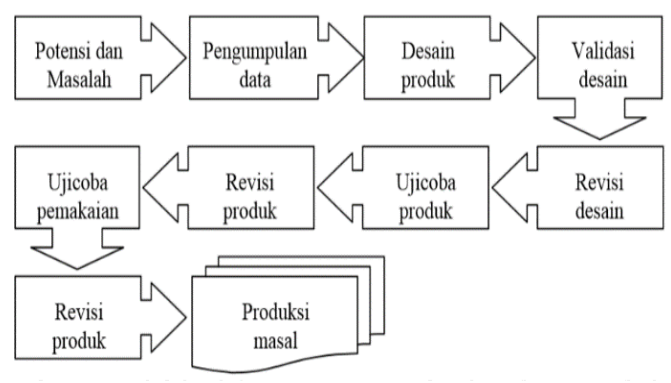

Gambar 1. Desain Pengembangan menurut Sugiyono

Beberapa hal yang akan diuraikan berkaitan dengan uji coba produk diantaranya:

1. Desain Ujicoba

2. Subjek Ujicoba

3. Ujicoba terhadap sasaran produk 
4. Jenis Data

5. Instrumen Pengumpulan Data

\section{Teknik Analisis Data}

Terdapat dua jenis analisis data yang digunakan, diantaranya:

\section{Analisis Statistik Deskriptif}

Merupakan analisis yang digunakan untuk data kuantitatif yang berbentuk angka. Pedoman penskoran media menggunakan skala Likert oleh Sugiyono (2016:166).

Tabel 1. Skoring Validasi

\begin{tabular}{cc}
\hline Kriteria & Skor \\
\hline Sangat Baik (SB) & 4 \\
\hline Baik (B) & 3 \\
\hline Tidak Baik(TB) & 2 \\
\hline Sangat Tidak Baik (STB) & 1 \\
\hline (Sumber : Sugiyono, 2016) &
\end{tabular}

- Data kelayakan

Berikut tabel tentang kesesuaian aspek dalam kelayakan menurut Arikunto (2010:158)

Tabel 2. Tabel Skala Persentase Uji Kelayakan

Presentase Penilaian Kategori

\begin{tabular}{cc}
\hline $81-100 \%$ & Sangat Layak \\
\hline $61-80 \%$ & Layak \\
\hline $41-60 \%$ & Cukup Layak \\
\hline $21-40 \%$ & Kurang Layak \\
\hline $0-20 \%$ & Tidak Layak \\
\hline
\end{tabular}

(Sumber : Arikunto, 2010)

- Data Kepraktisan

Berikut tabel tentang kesesuaian aspek dalam kelayakan menurut Riduwan(2012:41)

\begin{tabular}{cc}
\multicolumn{2}{c}{ Tabel 3. Tabel Skala Persentase Uji Kepraktisan } \\
\hline Presentase Penilaian & Kategori \\
\hline $81-100 \%$ & Sangat Praktis \\
\hline $61-80 \%$ & Praktis \\
\hline $41-60 \%$ & Cukup Praktis \\
\hline $21-40 \%$ & Kurang Praktis \\
\hline $0-20 \%$ & Tidak Praktis \\
\hline Sumber $:$ Riduwan, 2012)
\end{tabular}

\section{Analisis deskriptif}

Analisis deskriptif merupakan analisis yang digunakan untuk menganalisis data yang diperoleh melalui observasi awal, wawancara dan studi dokumentasi.

\section{HASIL DAN PEMBAHASAN}

Hasil penelitian dan pengembangan produk KOSAMI diuraikan dalam 2 tahapan yaitu aspek kelayakan dan aspek kepraktisan. Aspek kelayakan dilaksanakan pada tanggal 20 September 2018 s/d 05 Oktober 2018. 
Aspek kepraktisan dilaksanakan pada tanggal 08 Oktober 2018 s/d 13 Oktober 2018, diantaranya sebagai berikut :

\section{Aspek Kelayakan}

Pada aspek kelayakan dilakukan oleh ahli materi, ahli media dan ahli bahasa.

a. Validasi Oleh Ahli Materi

Hasil validasi oleh ahli materi disajikan pada tabel berikut :

Tabel 4. Hasil Validasi Ahli Materi

\begin{tabular}{llcc}
\hline No & \multicolumn{1}{c}{ Indikator } & Skor & Kategori \\
\hline 1 & Kesesuaian isi komik dengan kompetensi dasar & 3 & Baik \\
\hline 2 & Kejelasan topik pembelajaran & 3 & Baik \\
\hline 3 & Cakupan materi & 3 & Baik \\
\hline 4 & Ketuntasan materi & 3 & Baik \\
\hline 5 & $\begin{array}{l}\text { Keterkaitan contoh materi dengan kondisi yang } \\
\text { ada di lingkungan sekitar }\end{array}$ & 4 & $\begin{array}{c}\text { Sangat } \\
\text { baik }\end{array}$ \\
\hline 6 & Kejelasan contoh yang diberikan & 3,5 & Baik \\
\hline 7 & Ketepatan dialog/teks cerita dengan materi & 3 & Baik \\
\hline 8 & Keruntutan materi & 3 & Baik \\
\hline & Jumlah Skor & $\mathbf{2 5 , 5}$ & \\
\hline
\end{tabular}

Untuk mengetahui persentase kelayakan jumlah skor yang diperoleh dibagi dengan jumlah skor ideal masing-masing tiap indikator. Diperoleh persentase sebesar 79,69\% pada validasi ahli materi.

b. Validasi Oleh Ahli Media

Hasil validasi oleh ahli media disajikan pada tabel berikut :

Tabel 5. Hasil Validasi Ahli Materi

Penilaian Kelayakan Aspek Grafika

\begin{tabular}{|c|c|c|c|}
\hline No & Indikator & Skor & Kategori \\
\hline 1 & Ketepatan ukuran gambar dan ilustrasi & 3 & Baik \\
\hline 2 & Ketepatan bentuk gambar dan ilustrasi & 4 & Sangat Baik \\
\hline 3 & Keseimbangan proporsi gambar,ilustrasi dan teks & 4 & Sangat Baik \\
\hline 4 & Keterbacaan teks & 4 & Sangat Baik \\
\hline 5 & Kejelasan tata letak ukuran cerita & 3 & Baik \\
\hline & Jumlah Skor & 18 & \\
\hline \multicolumn{4}{|c|}{ Penilaian Kelayakan Aspek Penyajian } \\
\hline No & Indikator & Skor & Kategori \\
\hline 1 & Kejelasan alur cerita & 3 & Baik \\
\hline 2 & Ketepatan pemilihan karakter tokoh & 4 & Sangat Baik \\
\hline 3 & Kesesuaian gambar dengan cerita & 3 & Baik \\
\hline 4 & Kemenarikan gambar & 4 & Baik \\
\hline 5 & Ketepatan pemilihan jenis huruf & 4 & Sangat Baik \\
\hline 6 & Ketepatan dialog/teks cerita dengan materi & 3 & Baik \\
\hline 7 & Keruntutan materi & 3 & Baik \\
\hline 8 & Kesesuaain warna tulisan dengan background & 4 & Sangat Baik \\
\hline 9 & Kemenarikan buku sampul & 4 & Sangat Baik \\
\hline 10 & $\begin{array}{l}\text { Ukuran komik pas dan mempermudah siswa } \\
\text { untuk belajar }\end{array}$ & 4 & Sangat Baik \\
\hline \multirow[t]{3}{*}{11} & Perpaduan warna pada karakter tokoh & 4 & Sangat Baik \\
\hline & Jumlah Skor & 42 & \\
\hline & Total SKor & 60 & \\
\hline
\end{tabular}

Untuk mengetahui persentase kelayakan jumlah skor yang diperoleh dibagi dengan jumlah skor ideal masing-masing tiap indikator. Diperoleh persentase sebesar $93,75 \%$ pada validasi ahli media. 
c. Validasi Oleh Ahli Bahasa

Hasil validasi oleh ahli bahasa disajikan pada tabel berikut :

Tabel 6 Hasil Validasi Ahli Bahasa

\begin{tabular}{clcc}
\hline No & \multicolumn{1}{c}{ Indikator } & Skor & Kategori \\
\hline 1 & Ketepatan istilah & 3 & Baik \\
\hline 2 & $\begin{array}{l}\text { Kemudahan memahami alur materi melalui } \\
\text { penggunaan bahasa }\end{array}$ & 3 & Baik \\
\hline 3 & Kesantunan penggunaan bahasa & 3 & Baik \\
\hline 4 & Ketepatan dialog/teks cerita dengan materi & 4 & SangatBaik \\
\hline 5 & $\begin{array}{l}\text { Kesesuaian bahasa yang digunakan dengan } \\
\text { kemampuan berbahasa siswa SMP }\end{array}$ & 4 & $\begin{array}{c}\text { Sangat } \\
\text { Baik }\end{array}$ \\
\hline 6 & Ketepatan penulisan tanda baca & 3 & Baik \\
\hline & Jumlah Skor & $\mathbf{2 0}$ & \\
\hline
\end{tabular}

Untuk mengetahui persentase kelayakan jumlah skor yang diperoleh dibagi dengan jumlah skor ideal masing-masing tiap indikator. Diperoleh persentase sebesar 83,33\% pada validasi ahli bahasa.

d. Respon Guru Pada Aspek Kelayakan

Hasil respon oleh guru disajikan pada tabel berikut :

Tabel 7. Hasil Respon Guru

\begin{tabular}{clcc}
\hline No & \multicolumn{1}{c}{ Indikator } & Skor & Kategori \\
\hline 1 & Kejelasan contoh yang diberikan & 3 & Baik \\
\hline 2 & $\begin{array}{l}\text { Tata bahasa dan penyusunan kalimat pada komik dapat } \\
\text { dimengerti oleh siswa }\end{array}$ & 3 & Baik \\
\hline 3 & $\begin{array}{l}\text { Ketepatan waktu penggunaan media komik dalam } \\
\text { pembelajaran }\end{array}$ & 3 & Baik \\
\hline 4 & Fleksibilitas penggunaan media komik dalam pembelajaran & 3 & Baik \\
\hline 5 & Ilustrasi dalam media komik telah terstruktur & 3 & Baik \\
\hline & Jumlah Skor & $\mathbf{1 5}$ & \\
\hline
\end{tabular}

Untuk mengetahui persentase kelayakan jumlah skor yang diperoleh dibagi dengan jumlah skor ideal masing-masing tiap indikator. Diperoleh persentase sebesar $75 \%$.

e. Respon Siswa Pada Aspek Kelayakan Produk

Hasil respon siswa yang dilakukan oleh 8 orang siswa disajikan pada tabel berikut :

Tabel 8. Hasil Respon Siswa

\begin{tabular}{clcc}
\hline No & \multicolumn{1}{c}{ Pertanyaan } & \multicolumn{2}{c}{ Penilaian } \\
\cline { 2 - 3 } & & Ya & Tidak \\
\hline 1 & $\begin{array}{l}\text { Apakah penjelasan materi pokok media pembelajaran komik saku } \\
\text { matematika ini dapat dimengerti? }\end{array}$ & $100 \%$ & 0 \\
\hline 2 & $\begin{array}{l}\text { Apakah kamu menemui kesulitan dalam urutan cerita pada saat } \\
\text { membaca media pembelajaran komik saku matematika ini? }\end{array}$ & $12,5 \%$ & $87,5 \%$ \\
\hline 3 & $\begin{array}{l}\text { Apakah percakapan dalam media pembelajaran komik saku } \\
\text { matematika ini mudah dipahami? }\end{array}$ & $100 \%$ & 0 \\
\hline 4 & $\begin{array}{l}\text { Apakah karakter tokoh yang terdapat dalam media pembelajaran } \\
\text { komik saku matematika membuat kamu jenuh belajar? }\end{array}$ & 0 & $100 \%$ \\
\hline 5 & $\begin{array}{l}\text { Apakah media pembelajaran komik saku matematika ini dapat } \\
\text { membantu kamu dalam mengerjakan latihan? }\end{array}$ & $87,5 \%$ & $12,5 \%$ \\
\hline
\end{tabular}

Berdasarkan hasil respon oleh siswa diperoleh persentase sebesar 90,67\% dengan kategori penilaian sangat layak.

\section{Aspek Kepraktisan}

Adapun hasil aspek kepraktisan diuraikan sebagai berikut : 
Tabel 9. Hasil Tanggapan Guru

\begin{tabular}{clcc}
\hline No & \multicolumn{1}{c}{ Pernyataan } & Rata-rata & Kategori \\
\hline 1 & $\begin{array}{l}\text { Kemudahan media komik untuk memahami materi yang } \\
\text { disajikan }\end{array}$ & 3 & Baik \\
\hline 2 & Kemudahan memahami ilustrasi media & 3 & Baik \\
\hline 3 & Pemilihan warna dalam karakter telah sesuai dan menarik & 3,5 & Baik \\
\hline 4 & Kemenarikan tampilan komik & 4 & Sangat Baik \\
\hline 5 & Media komik aman digunakan & 4 & Sangat Baik \\
\hline & & $\mathbf{1 4 , 5}$ & \\
\hline
\end{tabular}

Untuk mengetahui persentase kepraktisan jumlah skor yang diperoleh dibagi denan jumlah skor ideal masing-masing tiap indikator. Diperoleh persentase sebesar 72,5\%.

Hasil aspek kelayakan dan kepraktisan diuraikan sebagai berikut :

Tabel 10.Ujicoba Skala Besar Layak

\begin{tabular}{clcc}
\hline No & \multicolumn{1}{c}{ Pertanyaan } & \multicolumn{2}{c}{ Penilaian } \\
\cline { 3 - 4 } & & Ya & Tidak \\
\hline 1 & $\begin{array}{l}\text { Apakah penjelasan materi pokok media pembelajaran komik } \\
\text { saku matematika ini dapat dimengerti? }\end{array}$ & $83,33 \%$ & $16,67 \%$ \\
\hline 2 & $\begin{array}{l}\text { Apakah kamu menemui kesulitan dalam urutan cerita pada saat } \\
\text { membaca media pembelajaran komik saku matematika ini? }\end{array}$ & $20 \%$ & $80 \%$ \\
\hline 3 & $\begin{array}{l}\text { Apakah percakapan dalam media pembelajaran komik saku } \\
\text { matematika ini mudah dipahami? }\end{array}$ & $100 \%$ & 0 \\
\hline 4 & $\begin{array}{l}\text { Apakah karakter tokoh yang terdapat dalam media pembelajaran } \\
\text { komik saku matematika membuat kamu jenuh belajar? }\end{array}$ & 0 & $100 \%$ \\
\hline 5 & $\begin{array}{l}\text { Apakah media pembelajaran komik saku matematika ini dapat } \\
\text { membantu kamu dalam mengerjakan latihan? }\end{array}$ & $73 \%$ & $27 \%$ \\
\hline
\end{tabular}

Berdasarkan hasil tanggapan siswa diperoleh persentase sebesar $87,33 \%$ dengan kategori penilaian sangat layak.

Tabel 11. Ujicoba Skala Besar Praktis

\begin{tabular}{clcc}
\hline No & \multicolumn{1}{c}{ Pertanyaan } & \multicolumn{2}{c}{ Penilaian } \\
\cline { 3 - 4 } & \multicolumn{1}{c}{ Ya } & Tidak \\
\hline 1 & $\begin{array}{l}\text { Apakah media pembelajaran komik saku matematika ini membuat } \\
\text { kamu menghabiskan waktu yang lama dalam memahami materi? }\end{array}$ & $13 \%$ & $87 \%$ \\
\hline 2 & $\begin{array}{l}\text { Apakah tampilan gambar dalam komik saku matematika ini } \\
\text { membuat kamu tertarik belajar? }\end{array}$ & $90 \%$ & $10 \%$ \\
\hline 3 & $\begin{array}{l}\text { Apakah alur cerita dalam komik saku matematika ini membuat } \\
\text { kamu cepat bosan? }\end{array}$ & 0 & $100 \%$ \\
\hline 4 & $\begin{array}{l}\text { Apakah komik saku matematika ini meningkatkan semangat kamu } \\
\text { untuk belajar? }\end{array}$ & $87 \%$ & $13 \%$ \\
\hline 5 & $\begin{array}{l}\text { Apakah alur cerita dalam komik saku matematika ini membuat } \\
\text { kamu bingung? }\end{array}$ & $10 \%$ & $90 \%$ \\
\hline
\end{tabular}

Berdasarkan hasil tanggapan siswa diperoleh persentase sebesar 90,67\% dengan kategori penilaian sangat praktis.

Penelitian dan pengembangan KOSAMI mengacu pada model pengembangan Sugiyono, yaitu:

\section{Potensi dan Masalah}

Berdasarkan hasil wawancara terhadap guru matematika kelas VII SMPN 7 Tarakan diperoleh informasi bahwa bahan ajar dalam pembelajaran berupa buku teks dan lembar kerja siswa, dalam proses pembelajaran buku teks/ pegangan yang digunakan dirasa kurang menarik bagi siswa dikarenakan kalimat terlalu panjang dan ukuran buku teks yang kurang praktis untuk dibawa kemana 
saja. Selain itu, pada saat peneliti melakukan observasi di SMP Negeri 7 Tarakan, siswa kurang tertarik ketika diarahkan untuk membaca buku mata pelajaran, siswa cenderung mencari gambar yang ada di dalam buku mata pelajaran tersebut, siswa juga merasa bosan dan mengalihkan kebosanan dengan membuat gaduh, berdiskusi sendiri dengan temannya, dan tidak memperhatikan guru yang sedang mengajar.

2. Pengumpulan Data

Pengumpulan data menunjang pengembangan produk berupa komik saku matematika untuk siswa kelas VII SMP.

3. Desain Produk

Desain produk pengembangan komik saku matematika mengacu pada spesifikasi produk yang dikembangkan, yaitu media pembelajaran matematika disajikan berupa komik saku matematika mengacu pada storyboard yang dibuat oleh peneliti

4. Validasi Desain

Validasi terhadap produk yang telah dikembangkan, validasi dilakukan oleh 2 ahli materi yaitu 1 Dosen Pendidikan Matematika dan 1 Guru Matematika SMP Negeri 7 Tarakan, 1 ahli media yaitu Dosen Pendidikan Biologi dan 1 ahli bahasa yaitu Dosen Pendidikan Bahasa dan Sastra Indonesia.

\section{Revisi Desain}

Revisi desain dari produk yang telah dikembangkan :

Validasi tahap pertama diberikan penilaian oleh validator namun hasil validasi tahap pertama memperoleh nilai dengan kriteria baik dan masih ada kesalahan-kesalahan menurut masing-masing validator.

6. Ujicoba Produk

Ujicoba produk, setelah validasi produk selesai dan perbaikan sudah di lakukan sesuai dengan saran-saran validator ahli materi, ahli media, ahli bahasa, respon guru dan siswa, dan memperoleh penilaian layak untuk menunjang proses pembelajaran langkah selanjutnya adalah menilai kepraktisan komik saku matematika dengan melakukan tahap ujicoba produk.

\section{Revisi Produk}

Ujicoba produk telah dilakukan oleh guru dan perwakilan 8 siswa kelas VII, diperoleh kategori penilaian sangat praktis,namun ada sedikit perbaikan dalam komik saku matematika yaitu lebih memperhatikan jawaban dari contoh soal dan memperbaiki latihan soal pada komik saku matematika, maka peneliti melakukan revisi produk. Perbaikan telah dilakukan, maka peneliti melanjutkan ke tahap berikutnya yaitu ujicoba pemakaian.

8. Ujicoba Pemakaian

Ujicoba pemakaian dilakukan dengan jumlah siswa terdiri dari 30 siswa kelas VII, siswa tertarik menggunakan komik saku matematika yang telah peneliti kembangkan. Berdasarkan ujicoba pemakaian yang dilakukan oleh siswa, diperoleh bahwa komik saku matematika yang dikembangkan memperoleh persentase sebesar 87,33\% dengan kategori sangat layak, dan persentase sebesar 90,67\% 
dengan kategori sangat praktis.

\section{KESIMPULAN}

Pada tahap potensi dan masalah, peneliti menggunakan pengembangan komik saku matematika sebagai potensi yang dapat dijadikan alat bantu untuk belajar mengajar di dalam ruang kelas maupun di luar kelas, dan peneliti menemukan suatu masalah dalam belajar peserta didik yaitu melakukan operasi pada bilangan. Tahap kedua pengumpulan data, pengumpulan data diperoleh dari sumber buku mata pelajaran siswa, buku-buku penelitian dan jurnal pendidikan.Tahap ketiga desain produk, desain produk di susun dalam bentuk storyboard. Tahap keempat validasi desain, produk divalidasi oleh ahli materi yang memperoleh persentase sebesar 79,68\% kategori layak, ahli media memperoleh persentase sebesar 93,75\% kategori sangat layak, ahli bahasa memperoleh persentase sebesar 83,33\%, respon guru memperoleh $75 \%$ kategori layak dan respon siswa memperoleh persentase $90,67 \%$ kategori kategori sangat layak.

Tahap kelima revisi desain, setelah produk di validasi oleh para ahli, maka akan dapat diketahui kelemahan dan kekurangannya, setelah diketahui kelemahan dan kekurangannya maka peneliti akan memperbaiki desain produk sesuai masukan para ahli. Tahap ke enam ujicoba produk, setelah mendapat kategori layak dari masing-masing para ahli, kemudian dilakukan ke tahap ujicoba produk kepada guru dan siswa. Ujicoba produk kepada guru memperoleh persentase sebesar 72,5\% kategori praktis. Tahap ke tujuh revisi produk, setelah dilakukan ujicoba produk, peneliti melakukan perbaikan terhadap saran-saram yang diberikan oleh guru dan peserta didik. Tahap ke delapan ujicoba pemakaian, pada ujicoba pemakaian diperoleh persentase sebesar 87,33\% kategori sangat layak dan pada ujicoba pemakaian aspek kepraktisan diperoleh perentse sebesar 90,67\%. Tahap ke Sembilan revisi produk, setelah dilakukan ujicoba pemakaian peneliti melakukan perbaikan terhadap saransaran yang diberikan peserta didik. Tahap terakhir produksi masal, setelah dilakukan perbaikan dalam komik saku matematika dan mendapat kategori layak dan praktis, komik di produksi di SMP Negeri 7 Tarakan sebanyak 15 komik dan di Jurusan Pendidikan Matematika sebanyak 5 komik.

\section{DAFTAR PUSTAKA}

Arsyad, Azhar. (2014). Media Pembelajaran. Jakarta : PT Raja Grafindo Persada. Arikunto, Suharsimi. (2010). Dasar-dasar Evaluasi Pendidikan. Jakarta : Bumi Aksara. Hizair. (2013). Kamus Lengkap Bahasa Indonesia. Jakarta : Tamer. Indriana, Dina. (2011). Ragam Alat Bantu Media Pengajaran. Yogyakarta : DIVA Press. McCould, Scott. (2008). Memahami Komik. Jakarta : Kepustakaan Populer Gramedia. Riduwan. (2012). Dasar-dasar Statistika. Bandung: Alfabeta.

Rusman. (2012). Belajar dan Pembelajaran Berbasis Komputer : Mengembangkan Profesionalisme Abad 21. Bandung: Alfabeta.

Sugiyono, (2016). Metode Penelitian Pendidikan Pendekatan Kuantitatif, Kualitatif, $R \& D$. Bandung: Alfabeta.

Susilana. (2008). Media Pembelajaran. Kurtekpend Upi : Bandung. 